\title{
近江のなれずし
}

\author{
堀越昌子 \\ (滋賀大学教育学部)
}

\section{Traditional Fermented Fish in Shiga}

\author{
Masako HoRikoshi
}

(Shiga University, Hiratsu, Otsu 520-0862)

\section{1. はじめに}

滋賀には琵琶湖があり，その周りに水田が広がってい る. 食生活は豊かな米と淡水魚の組合せを軸に構成さ れ，栄養的にバランスのとれた優れた食事パターンが形 成されてきた。 日本の伝統食は, 従来, 良質のタンパク 質とカルシウムと脂質が不足していたが, 琵琶湖周辺で は湖魚を食べることによって, それらの供給が図れ, 人々の健康に大きく貢献してきた. 湖魚は刺身, なます, 煮魚, 飴煮, 豆煮, 焼魚, 鍋, 汁, なれずしなどにされ, 多様な淡水魚利用文化が形成されている. とりわけ琵琶 湖周辺のなれずし文化は, 他府県にないユニークさを 持っており, 琵琶湖で獲れるほとんどの魚がなれずしに される. 本報では，この湖魚のなれずし文化に焦点を当 てて報告する．

\section{2. なれずしとは}

なれずしとは, 魚肉や獣肉などをデンプン質のもので 発酵させた漬物である2). なれずし加工法は，デンプン 質を好む乳酸菌を選択的に増殖させて, 魚獣肉の長期保 存とうま味・風味の増加をねらうあのである.

モンスーンアジア地域では高温多雨の気候を活かし， 特有の発酵技術が発達してきた。豊かな微生物資源を基 盤に, 魚酱, 塩辛, なれずし, 野菜の漬物類, 大豆酱油, 味増, 納豆などアジア独特の多様な発酵食品を産み出し てきた。 日本でも獲れる魚をなれずしに漬けてきた長い 歴史がある. 現在は作成圏が縮小してしまったが, 海産 魚のいずし, なれずし, 糠漬けが北海道, 東北, 福井, 富山, 和歌山に残っている. 淡水魚のなれずしに関して は, 現在, 琵琶湖周辺に最むよく残っている.

アジアのなれずしは，魚をご飯で漬け込んだものが圧 倒的に多い. 東アジアから東南アジアにかけては, 稲作 文化圈である。モンスーンアジア地域は年間 $1,000 \mathrm{~mm}$

函520-0862 滋賀県大津市平津 $2-5-1$
以上の降水量に恵まれており，豊かな雨が，稲作と淡水 魚資源を育んでくれた。したがって「米で発酵させた魚 のなれずし」は，モンスーンアジアの象徴的な存在とい える、熱帯モンスーンアジアでは魚を 3 日ほど発酵させ るとなれずしになる（図 1). 発酵させるご飯屯熱帯では 多くを必要としないが，温帯の日本では魚とほぼ同量の

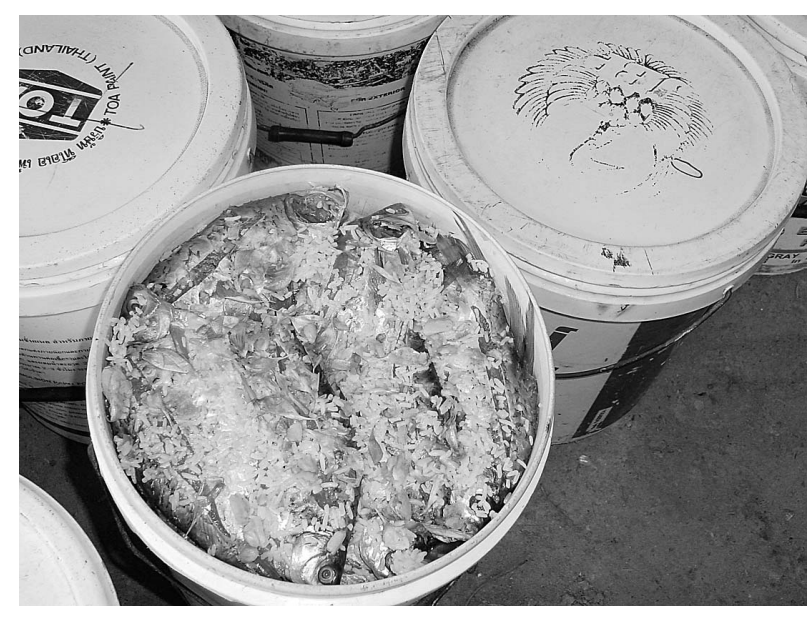

図1.タイのパーソム

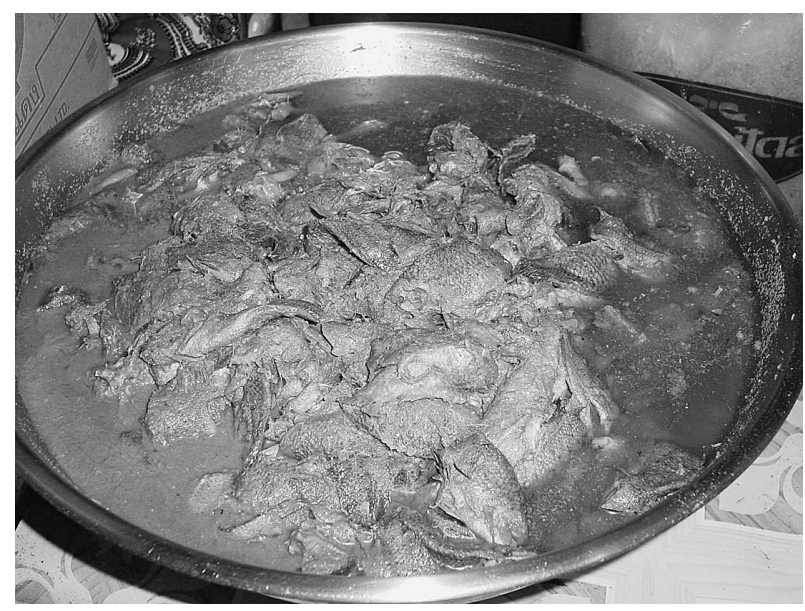

図2. タイのプララー 


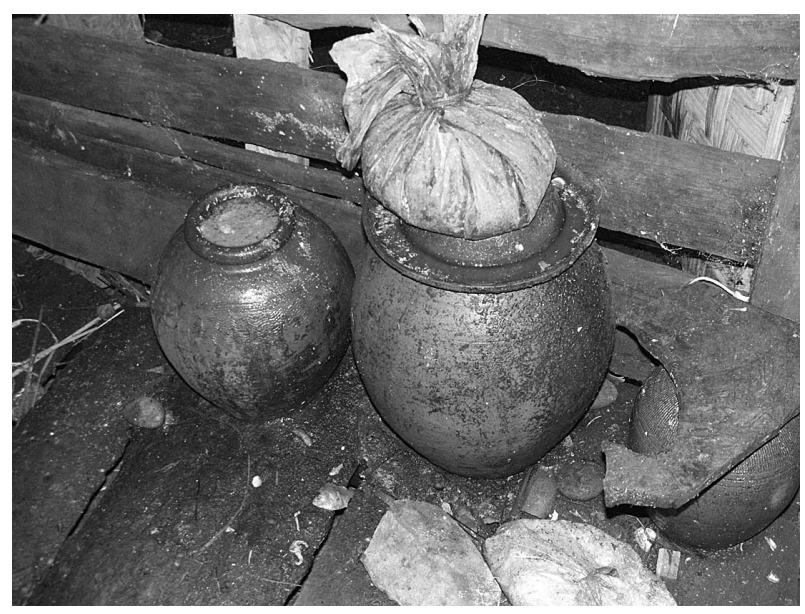

図 3. ラオスの民家で漬けるパデークの畺

ご飯を用いて漬ける. 小魚の早なれずしで 2 週間前後, 大きめの魚は半年から 2 年間かけて熟成させる. 熱帯ア ジアには魚の発酵食品としてほかに, 魚奨油（ナンプ ラーなど）や多彩な塩辛類（プララー，パデークなど） があり, 汁物, 煮物, 炒め物, サラダの味付けに欠かせ ない存在となっている（図 2,3 ).

\section{3. 琵琶湖の魚貝と食べ方の特徵}

琵琶湖には豊かな淡水魚貝が住んでおり，その多くが 固有種である. 琵琶湖は, 深い所で $100 \mathrm{~m}$ の深さがあ り, 温度域が広い. また湖岸の砂地や岩場, 内湖域, 莘 原, 川, ため池, 水田など多様な環境があり, 多種類の 魚貝を育んできてくれた。

人々は縄文の昔から, 琵琶湖の魚貝を糧としてきた。 9,300 年前, 4,500 年前の粟津湖底遺跡から大量のシシ ミの殼, コイ, フナ, ギギなどの骨が出土しており, 当 時の人々は魚貝から必要熱量の半分を得ていたと推定さ れている6).

琵琶湖周辺で生きてきた人々は, 淡水魚貝の多彩な加 工法, 料理法を開発し発展させてきた. 湖魚の特徵的な 食べ方として，次の 4 点を挙げることができる.

第 1 の特徵は, 刺身, せごし, なますなどにして生の まま食べることである，鯉の洗い，鮒の子つけは，祭り のご馳走である. 小骨の多いハスやウグイはセゴシ（骨 ごと薄く刻む）にして辛子酢味噌で食べる.

一般に淡水魚の生食は寄生虫を恐れて敬遠される。し かし琵琶湖周辺では, 淡水魚を生で普通に食べてきた. このことは世界的にあ珍しいことであるといえる．この 理由は, 琵琶湖が近年まできれいな水質を誇ってきたこ とによっている. 琵琶湖周辺では, 水道が設置されるま で，湖水を直接飲み水として利用してきた長い歴史があ るし, 琵琶湖の魚たちも水質のきれいな環境に適応して きたものばかりであり, 刺身で食べても生臭くない，ビ ワマスの刺身はマグロのトロ以上といわれている（図 4). 辛子酢味噌で食べるフナの刺身むおいしい. 琵琶湖
の魚を長く生食していても重篤な寄生虫被害にあった例 は聞いていない.

第 2 の食べ方の特徵は, 小魚の煮物文化である.コア ユ, ホンモロコ, ゴリ，イサザ，七夕シジミどを煮付 けて骨ごと食べる。最近でこそ煮魚を購入する人が増え てきているが，一昔前は，生魚で購入し，自分の家で者 つけるのが普通であった。こういった煮魚文化は湖岸ば かりでなく, 琵琶湖の周囲 $10 \mathrm{~km}$ 圈内に広がっている. 農村部であ生の湖魚が行商で売られていったので，小魚 を炊いて日々のおかずにしてきた。 小鮎の佃者（図 5) が最も消費量が多く，ほかに，えび豆，イサザ豆，セ夕 シジミ豆など大豆と煮付けて食べることも多い.

第 3 の特徵は, 湖魚をすき焼き鍋にすることである. ウナギ，ナマズ，イサザなどが鍋によく使われる，たっ ぷりの牛蒡のささがきをネギと一緒にすき焼き鍋に入れ ると，あっさりとおいしく食べられる（図6）.

そして第 4 に最む特徴的な食べ方といえるのが，ご飯 と一緒に湖魚を発酵させる「なれずし」である。なれず し加工法は冷蔵庫, 冷凍庫のなかった時代には必要不可 欠の保蔵法であった。琵琶湖周辺には現在でも多様な淡 水魚のなれずしが存在する. 最む有名なのがフナずしで

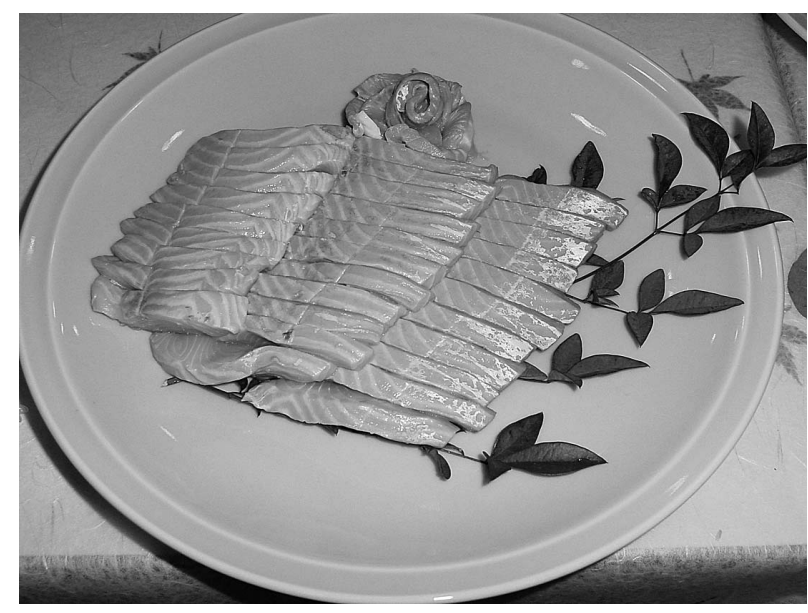

図 4. ビワマスの刺身

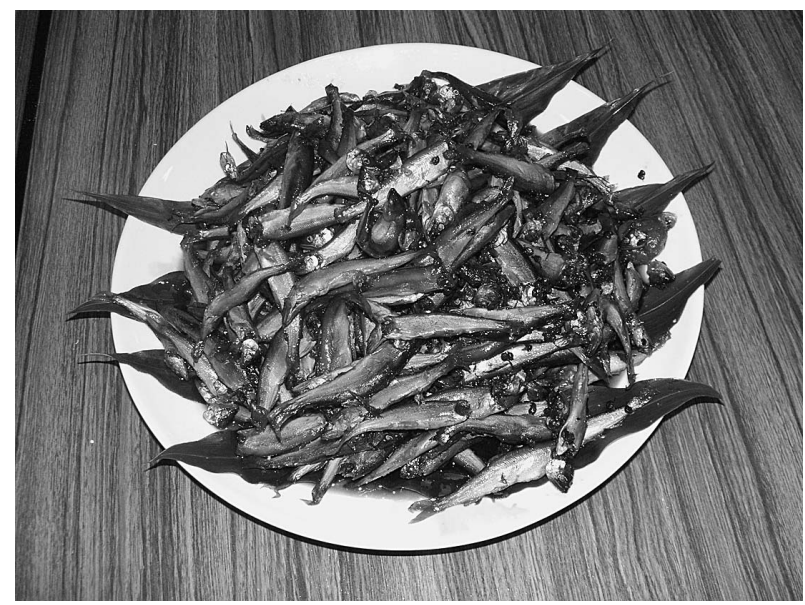

図 5. 鮎の佃者 


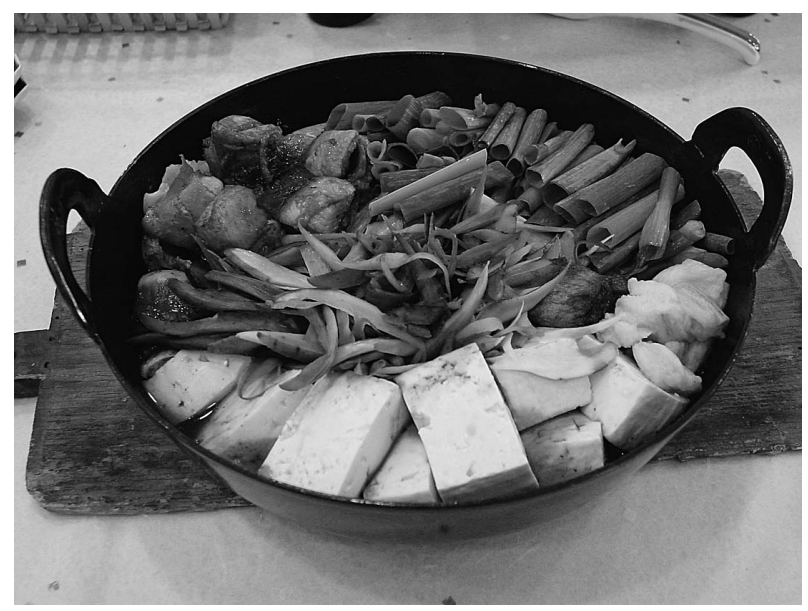

図 6. うなぎのすき焼き

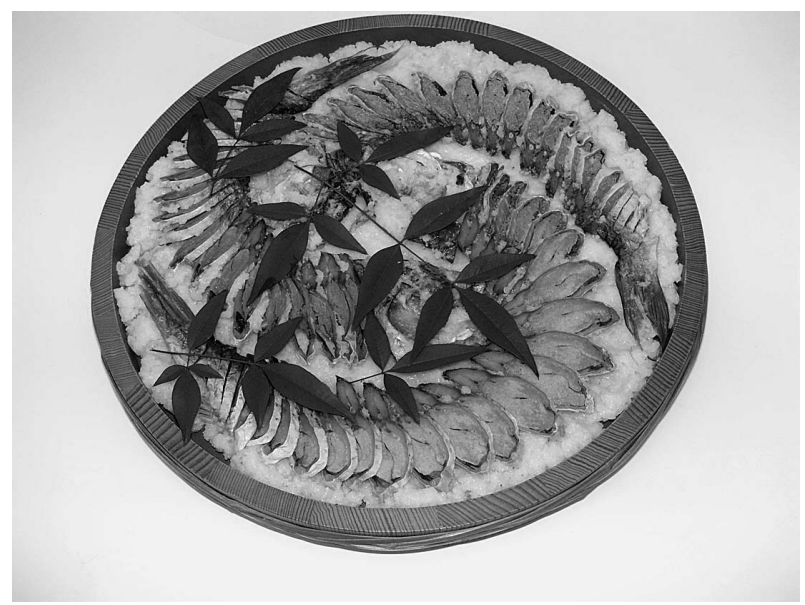

図 7.フナずし

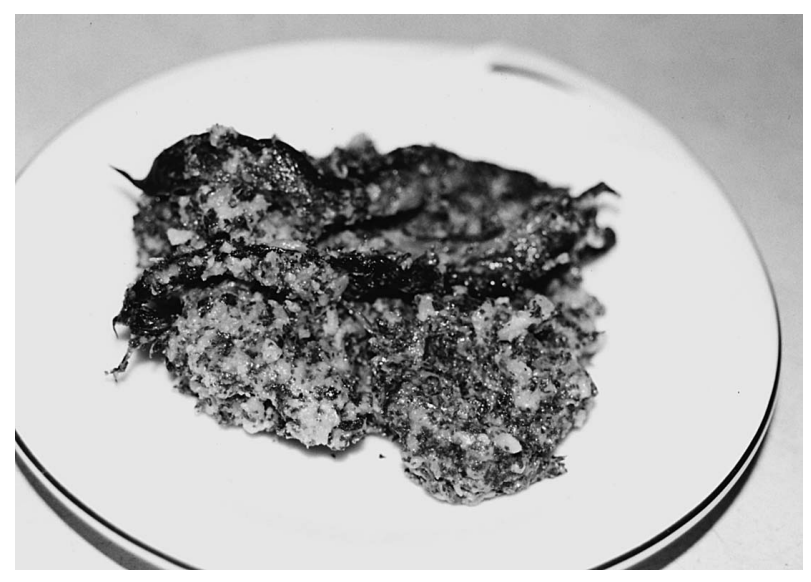

図 8. ドジョウずし

ある7). 他に, 八スずし, ウグイずし, コイずし, モロコ ずし，アユずし，オイカワずし，ビワマスずし，ナマズ ずし，ドジョウずしなど，多彩ななれずし文化が形成さ れている8). 湖魚はそれぞれ大きさも肉質も違っており, なれずしとしてできあがった味や匂いにあ個性がある.

(図 $7 \sim 9$ ).

淡水魚は海産魚に比べて保存がきかず, 乾燥するか,

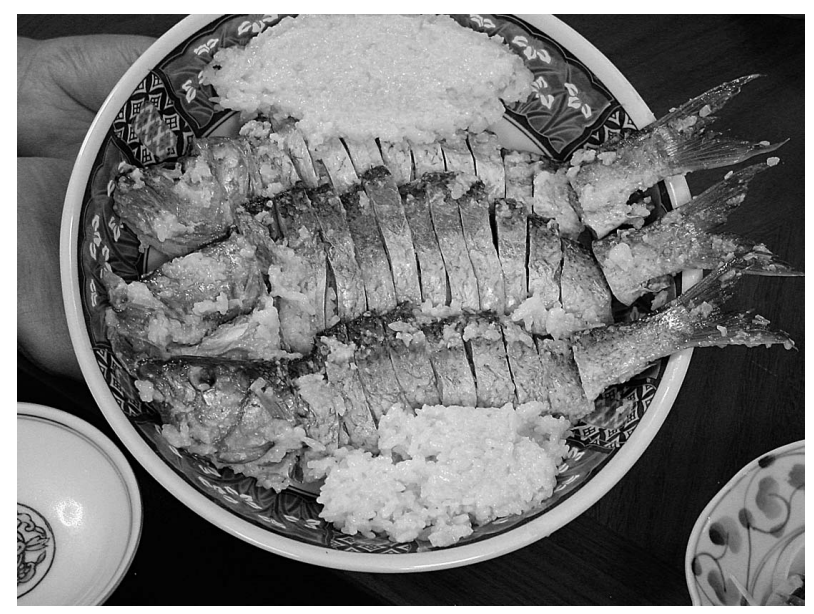

図 9.八スずし

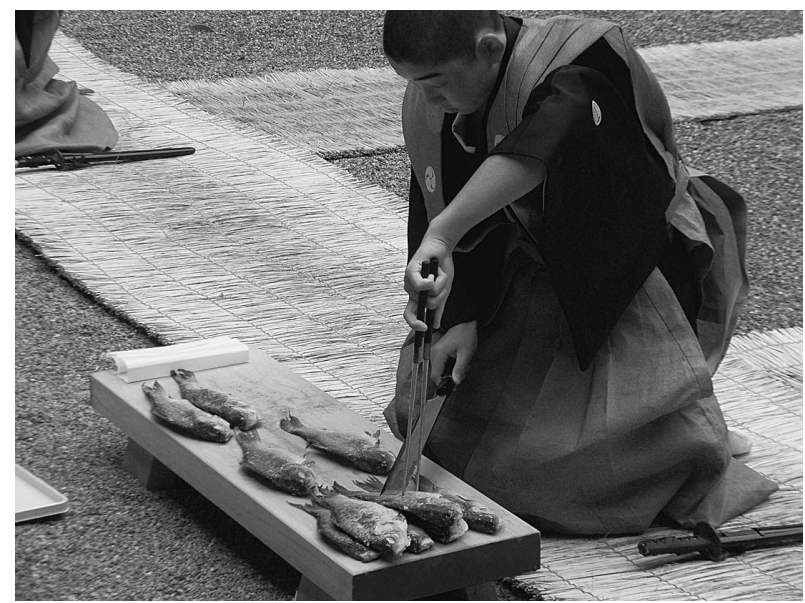

図 10. 守山市下新川神社のすし切り神事

塩で押しておくしかない。 その中で加工・貯蔵法として 風土にも合った優れた保存方法が，米で乳酸菌を増殖さ せるこのなれずし発酵法である。琵琶湖での漁獲量には 季節变動があり, 春から夏にかけて集中して魚がとれ る。それらを腐らさずに保蔵する方法として，なれずし 法が選ばれてきた。琵琶湖で獲れるほとんどの魚がなれ ずしにされてきた。

琵琶湖周辺の淡水魚なれずし文化は, その種類の豊富 さ，生活との密着度，近代化された食生活の中でも継承 されてきたところが注目に值する。なれずしは滋養・保 存食であるが，同時に正月，オコナイ，祭りなど晴れの 日の特別食であり，時には薬にもなった．

滋賀では神社のお祭り，正月など客呼びのご馳走とし て，なれずしが登場することが多い。野洲川河口に近い 守山市の幸津川では，5月5日の下新川神社で「すし切 り」神事（図 10）が行われ，フナずしが神饌として奉納 される. 栗東市大橋では「ドジョウずし」, 高島市マキノ 上開田では「ウグイずし」が春祭りの神饌として登場す る。これらは琵琶湖周辺の特有の文化であり, 稲作とな れずしの結びつきを表している，魚のなれずしは稲作の 民が開発し発展させてきた技術であり, なれずし手法 
は, アジアモンスーン圈の暑くて湿気の多い風土に不可 欠であり，魚を長期間保蔵するための優れた技術である といえる。

\section{4. 湖魚なれずしを漬ける}

なれずしは，魚を数力月間塩漬けしてから，ご飯と漬 け込み, 重石で押し嫌気的条件下で乳酸菌発酵を進めて いくので, 大きく塩漬け作業（塩切り）と飯漬け作業に 分けられる。

材料の魚は生きた状態の新鮮なむのを使うことが大事 である。まず鱗と鰓，内臟をとり除く。小魚の場合は， 腹をカットして内臟を出すだけでよい，空隙部をよく 洗って, しっかり塩をあててから桶に漬け, 重石をして 2 力月以上は保蔵する。これが塩切り作業である.

その後, 塩押しできた魚は丁寧に洗って, 干して水を 切ってから, ご飯で本漬け (飯漬け作業) する. 魚の鰓 や内臟の空隙部にご飯を詰め, 飯層の上に魚を平らに並 べ, 魚層, 飯層, 魚層, 飯層と重層していく，上までき たら竹皮等で覆い，重石を置く。フナずしの場合，塩切 魚 $10 \mathrm{~kg}$ に対し米を 3 ～4 升ほど使う。 八スずしの場合 は，塩切魚 $5 \mathrm{~kg}$ に米 2 升を使用する。なれずしによっ ては敖を足したり，生姜，山椒を入れる場合がある（図 11〜13)

なれずし発酵の進行役は乳酸菌である。乳酸菌を漬床 に増殖させることによって, 腐敗しやすい生魚を半年か ら 2 年間も保存できる. 魚の塩漬け中には乳酸菌は增え ず，飯漬け段階で爆発的に増殖して発酵を推進してい く. 乳酸菌に関しては藤井らのほか, 磯部らなどいくつ かの報告がある ${ }^{1,7,9)}$.

琵琶湖で獲れる魚は基本的に何でむなれずしにされ る. 大きい魚は数力月から 1 年かけて本なれずしにし, 小魚はご飯と $1 \sim 2$ 週間漬けて生なれずしにする。 八ス

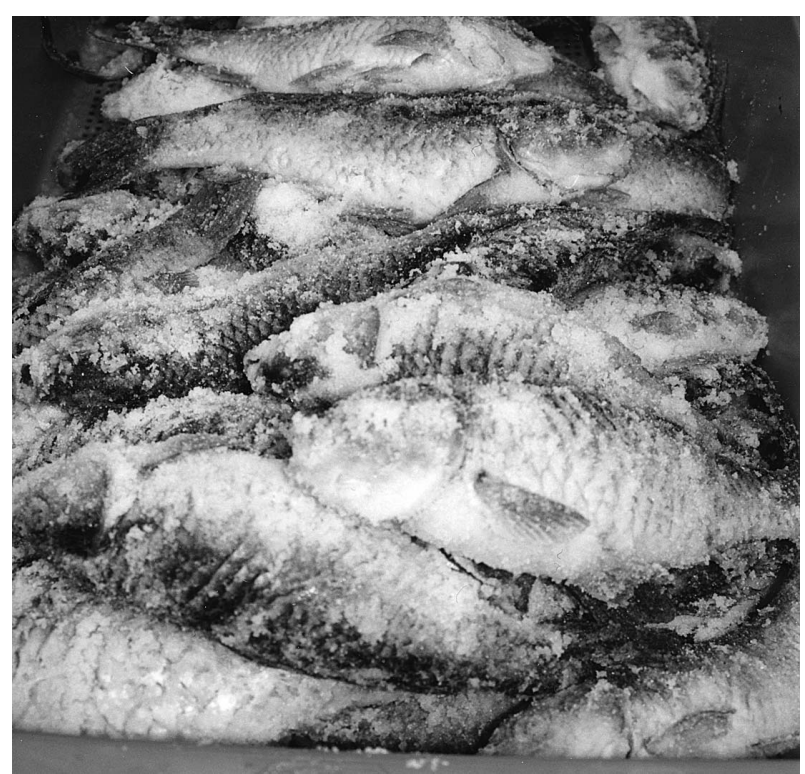

図 11. フナずしの塩切り作業

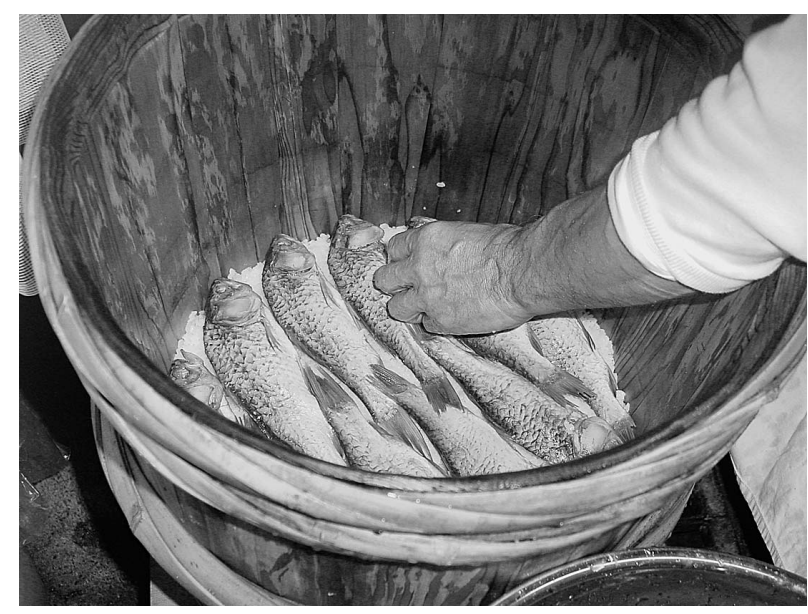

図 12.フフずしの飯漬け作業

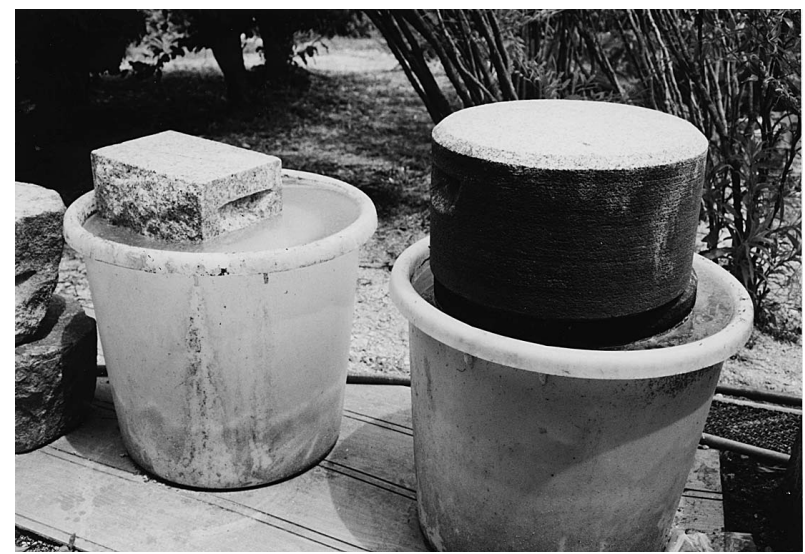

図 13.なれずしの桶

ずし，オイカワずしなど，雑魚の生なれずし類は，魚が 捕れたときにまず塩漬けにしておき，食べたい日から逆 算して飯漬けの日程を決める。 1 2 週間という短期間 しか発酵させないので，ご飯は粒状に残り，魚と一緒に 飯あ食べるのが特徴である。魚はそれぞれ個性があり， なれずしになっても持ち味が残る。家々で野菜の漬物を 漬けるような感覚で湖魚のなれずしが漬けられてきた。 一軒当たりの漬ける量は，フナの場合は $10 \mathrm{~kg}$ ほよ゙，他 の魚の場合は，2〜 $5 \mathrm{~kg}$ ほどである．漬け方にはそれぞ れ家の流儀があって, 塩加減, ご飯の量, 水の交換法に 違いが見られ，仕上がり状態も熟れ加減，匂い，香り， 味に微妙な違いが出てくる.

\section{5. なれずしの熟成と制御方法}

乳酸菌が漬床で増殖し，なれずし魚体は産生してきた 有機酸やプロテアーゼの作用を受けて, 徐々に熟れてい く．小魚の場合 2 週間前後で食べられるが， $300 \mathrm{~g}$ 以上 の魚では半年から 2 年かけて熟成させる. 発酵期間の短 い生なれずしは，食べる日程に合わせて飯漬けするが， 特に温度管理に神経を使う。

なれずしが熟れていく過程は，温度，使用飯量，塩分 濃度によって左右される。早く仕上げたい場合は，温度 
を高めに，ご飯量を多くし，塩分を控える，逆にゆっく り進行させる場合は, ご飯を減らし, 塩分は多めにして, 桶を涼しいところに置いて管理したり, 季節をずらせた りする。一般にフナなど大きい魚の本なれずしは， 7 月 から 8 月の真夏にかけて飯漬けをする. 飯漬けして一気 に発酵を進ませる必要があり, 冷夏の年には失敗するこ とがある。

なれずしの漬け床は，重石で押されて酸素が追い出さ れ嫌気的条件下に置かれるので，2 年経過したなれずし 魚体中の高度不飽和脂肪酸 (DHA, EPA) は酸化されずに 新鮮な状態で保たれている。このことだけであ伝統的な なれずし加工法がいかに優れているかがわかる.

なれずしの発酵過程では独特の酸味, 風味，うま味が 醸し出されてくる. 発酵過程における大きな変化は, 魚 肉タンパク質がプロテアーゼの作用を受けて, 分解され ていくことである. 魚肉タンパク質が徐々に分解されて いき, アミノ酸が増加して, うま味が醇し出されてくる. 遊離アミノ酸含量を追っていくことでその発酵過程を知 ることができる4).

また骨が軟化してくるのもなれずしの特徴で，硬い不 溶性の骨塩カルシウム（炭酸カルシウム, リン酸カルシ ウム) が, 産生してきた有機酸で徐々に溶かされ, 乳酸 カルシウムなどに变化していき, 骨ごと食べられるよう になる。

乳酸, 酢酸, 酪酸などの有機酸産生量は, 漬け床の $\mathrm{pH}$ の動向でわかる. うまく発酵が進行すると $\mathrm{pH}$ が一気に 4 付近まで下がり, 主成分の乳酸は $2 \%$ 近くまで上が る. 産生される有機酸のうち, 乳酸に次いで多いのは䣷 酸である.

\section{6. フナずし独特の匂い}

フナずしは独特の匂いを持っている，好きな人には魅 力だが，嫌いな人には強烈な匂いである，なれずしの匂 い成分は発酵の進行ともに劇的に変化する。 また漬ける 人によって，環境によっても変化する.

SPME 吸着法により揮発成分を吸着し, GCMS に よって分析・同定を行ったところ，検出された揮発成分
数は約 30 種類であった ${ }^{3)}$ (表 1, 図 14). それらの多く は，酸，アルコール，エステルで，ほかにアルデヒド， ケトン, 酸, フランが検出された. どのフナずしからむ 検出される物質は 12 種類あり, そのうち比較的多いの は, 酢酸エチル, 乳酸エチル, 1-プロパノール, エチルア ルコール, $\beta$-フェニルェチルアルコールと䣷酸であっ た1). 熟れすぎると酸味が上昇し，エステル臭がきつく なる.

家々で漬けたものは強烈な風味のものが多い，漬ける ときの飯量や塩分に差があり，その後の温度管理や水管 理，漬ける期間にも差があるので，漬け上がったフナず しは，さまざまな味と匂い，香りを持つようになる．塩 辛さ, 酸っぱさ, 発酵臭に微妙な違いができるのである. 有機酸やエステル，アルコールなどの芳香成分のほか に，ケトンやアルデヒドなどの腐敗臭・生臭さに近い成 分が検出される。それらの成分スペクトルが家ごとに 違っているのである。 その個性的な味とにおい・かおり が忘れられない我が家の味となっているのである.

くせの強い食品だけに，臭みを抑えたフナずしを作ろ うという試みも一方である。若い人にも初めての人にも 抵抗のないようにと，飯に麹をふったり，飯で二度漬け したり，酒粕で仕上げる試みあある。しかしフナずし通 にはそれらは概して不評である。個性的な味や風味を消 してしまったら元む子あない.フフずしのうまさまで消 してしまう。本末転倒だというわけである。うまさの中

表 1.フナずしの主要な匂い成分

\begin{tabular}{|c|c|}
\hline & 匂い成分 \\
\hline 酸 & $\begin{array}{l}\text { 乳酸 } \\
\text { 酢酸 } \\
\text { 酪酸 }\end{array}$ \\
\hline アルコール & 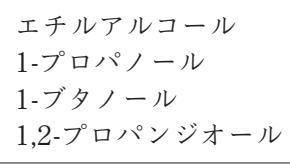 \\
\hline エステル & $\begin{array}{l}\text { 䣷酸エチル } \\
\text { 䣷酸-n-プロピル } \\
\text { 乳酸エチル }\end{array}$ \\
\hline
\end{tabular}

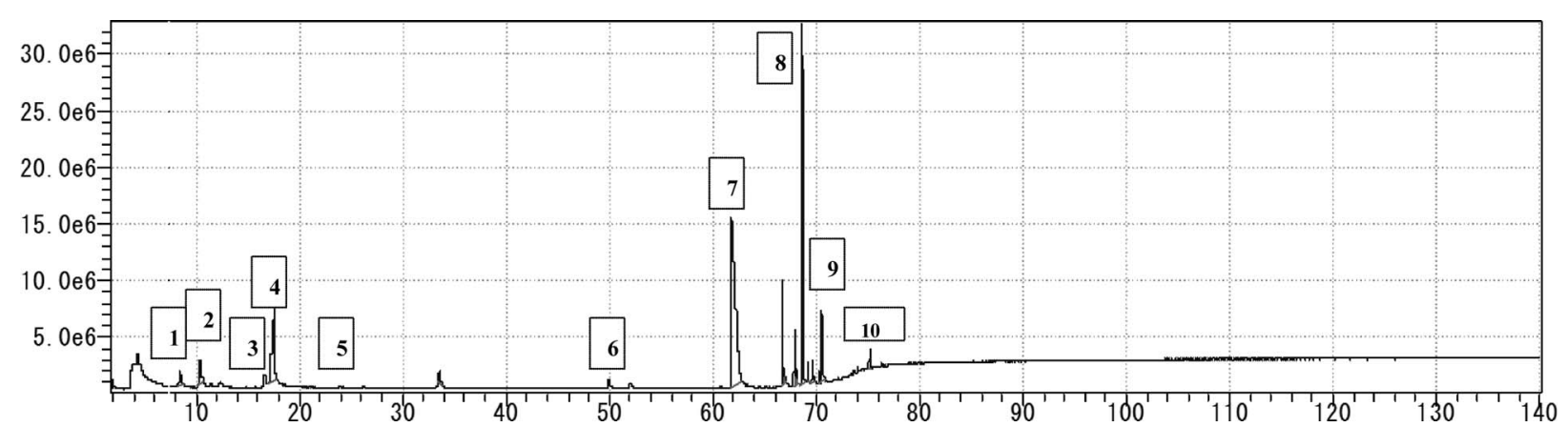

図 14. フナずし飯の揮発性成分

1: ethyl acetate, 2: ethanol, 3: propyl acetate, 4: 1-propanol, 5: 1-butanol, 6: ethyl lactate, 7: acetic acid, 8: 1,2propan diol, 9: butanoic acid, 10: phenylethyl alcohol 
身には，単に口当たりのよい味やかおりだけではなく， 癖のある臭さむ大切な要素として含まれているのであ る.

\section{7. なれずしと食中毒}

東南アジアでは，なれずし（パーソム，ソンパーなど） は焼いたり揚げたりと加熱して食べることが多い.しか し日本では漬けた物をそのまま食べることが基本であ る.ご飯をたっぷり使って半年以上の長期間にわたって 発酵させた本なれずしでは食中毒が起こったことはな い.しかし短期間で仕上げた生なれずしでは，1973 年 と 1989 年の 2 件, ボッリヌス食中毒が起こった。 2 件 とも， 2 週間ほどで仕上げた自家製ハスずしで起こって おり，鰓の残存や塩押し期間が短すぎた場合に食中毒の 危険性が高くなる，半年以上長く漬ける本なれのフナず しで食中毒が起こったことはなく, 発酵という微生物の 力を借りた保蔵技術の威力を感じとることができる.

\section{8. なれずしの効能と抗菌性}

なれずしは, タンパク質, 脂質, ミネラル, ビタミン 等を供給してくれる滋養食品である。またなれずしは生 菌食物であり，プロバイオティクスとして，整腸作用や 免疫賦活作用が期待できる.

滋賀では昔からフナずしは，祭りの食としてだけでな く, 滋養食, 民間薬として知られてきた。風邪やお腹を 壊したとき，フナずしを食べて癒してきた。

2010 年 1 月に，フナずしの効能に関する民間伝承を 調査 (調査対象者 544 名) したところ，「お腹をこわした ときに食べるとよい」は，44\%の人が知っており，「腸 の善玉菌を増やしてくれる」33\%,「免疫力を上げる」 14\%，「風邪をひいたときによい」13\%，「冷え性によ い」5\%，「血清コレステロールを下げてくれる」5\%, 「高血圧によい」4\%であった。ほかに「ガンに効く」と あげた人もあった（表 2 ).

研究室では発酵させたフナずし魚体と漬床の発酵飯が 抗菌力を持つことをバレイショ菌および大腸菌を使って 確認してきた。発酵飯と直接接触させたゲル拡散法で, 阻止円面積で抗菌力を比較したところ，2 年経過したフ ナずし発酵飯でも, バレイショ菌, 大腸菌に対して高い 抗菌性を確認することができた（図 15)。抗菌性は有機

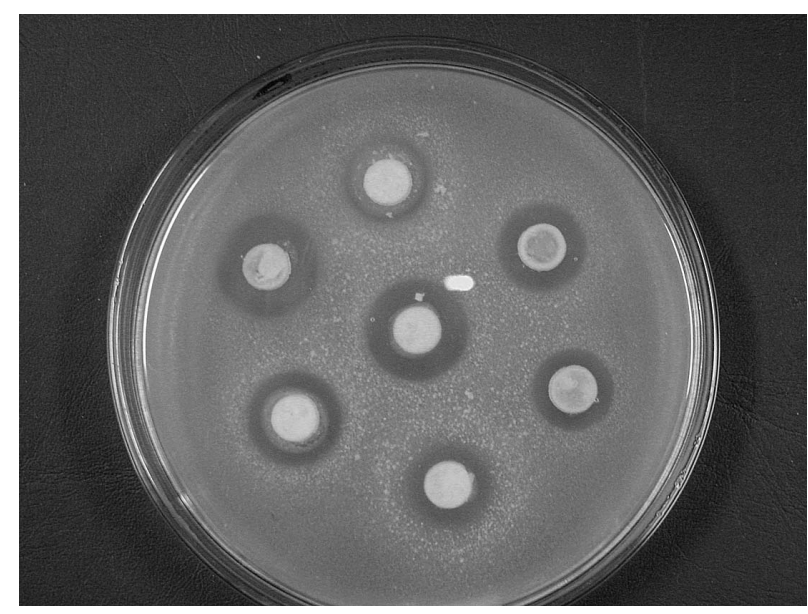

図 15.フナずしの抗菌性

酸やバクテリオシンが関与しているとの報告がある。詳 しい分析はこれからであるが，産生した酢酸む抗菌性に 関与していることはフナずしでも確認できた ${ }^{8)}$.

滋賀の人々に永く愛されてきた湖魚のなれずし類. そ の魅力と効能が科学的にも明らかにされる日は近いと期 待している.

\section{9. 最 後 に}

滋賀県では「滋賀の食文化財」5) (平成 10 年) として, 湖魚の佃煮, 湖魚のなれずし, アメノイオご飯, 日野菜 漬け，でっち羊美の五つが選ばれている。湖魚のなれず し文化は，琵琶湖を中心にして，滋賀県下一円に広がっ ており，多くの人がなれずしを発酵する技術を持ってい る。その食習俗が選ばれた理由であり，湖魚のなれずし は，滋賀を代表する味覚である.

野菜の漬物, 味増, 奨油, 納豆, 酒, なれずしなど, 庶民が当たり前に作ってきたこれらの発酵食品が，現在 は購入するものに变わりつつある. 数千年間にわたって 保持してきた庶民の発酵技術が，その手から離れて急速 にしぼみつつあることは残念である。滋賀のなれずし文 化むフナ資源量の減少や価格の高騰で縮小気味であった が，稚魚放流や水田プロジェクト（水田で湖魚の孵化・ 育成を図る）の努力でここ 2 年間は, 琵琶湖のニゴロブ ナの資源量が少し増加傾向にある，琵琶湖の水質と魚貝 を守って伝統的な湖漁食文化を伝承していきたい，なれ

表 2. フナずしの効能に関する民間伝承

\begin{tabular}{|c|c|c|c|c|c|c|}
\hline & 30 代まで & 40 歳代 & 50 歳代 & 60 歳代 & 70 歳以上 & 全体 \\
\hline お腹によい & $17.8 \%$ & $22.1 \%$ & $30.1 \%$ & $55.3 \%$ & $63.3 \%$ & $43.8 \%$ \\
\hline 風邪をひいたとき & $12.2 \%$ & $7.4 \%$ & $10.8 \%$ & $11.3 \%$ & $18.4 \%$ & $12.9 \%$ \\
\hline 免疫力を上げる & $10.0 \%$ & $11.8 \%$ & $14.5 \%$ & $17.6 \%$ & $12.2 \%$ & $14.0 \%$ \\
\hline 冷え性によい & $5.6 \%$ & $0.0 \%$ & $4.4 \%$ & $7.9 \%$ & $6.8 \%$ & $5.0 \%$ \\
\hline 高血圧によい & $1.1 \%$ & $2.9 \%$ & $1.2 \%$ & $6.3 \%$ & $5.5 \%$ & $4.0 \%$ \\
\hline 善玉菌を増やす & $25.5 \%$ & $27.9 \%$ & $39.8 \%$ & $42.1 \%$ & $25.2 \%$ & $32.9 \%$ \\
\hline 血清コレステロール低下 & $0.0 \%$ & $2.9 \%$ & $6.0 \%$ & $7.5 \%$ & $4.8 \%$ & $4.8 \%$ \\
\hline
\end{tabular}

（2009 年 9 月〜2010 年 2 月に調査を実施した。対象者は 544 名） 
ずし発酵技術を，またなれずしを愛する味覚，嗅覚を失 わないでいきたいあのである.

\section{謝辞}

教育講演の機会を与えていただき，日本食品微生物学 会に深く感謝します.

\section{文献}

1) Fujii, T., Nishi, T. and Okuzumi, M.: Chemical composition and microbial flora of funazushi, crucian carp fermented with rice. Yamawaki Stud. Art. Sci., 46, 90-103 (2008).

2) 石毛直道, ケネス・ラドル：魚奨となれずしの研究. 岩 波書店, 東京 (1990).

3) 久保加織, 西 恭兵, 堀越昌子：なれずしの香りとにお い. におい・かおり環境学会誌，38，173-178 (2007).

4) Kubo, K. M., Ogawa, Y. and Horikoshi, M.: The effects of free amino acids, nucleic compounds, and volatile constituents of funazushi (fermented sushi of crucian carp (Cyprinus auratus)) on preference. J. Sci. Food Agric., 88, 1259-1265 (2008).

5）滋賀県文化財保護課：滋賀県の伝統食文化. 滋賀県教育 委員会編, 滋賀 (1998).

6) 滋賀県教育委員会, (財)滋賀県文化財保護協会：粟津貝 塚湖底遺跡. 滋賀県教育委員会, (財)滋賀県文化財保護 協会編, 滋賀 (1984).

7）滋賀の食事文化研究会：ふなずしの謎. サンライズ出版, 滋賀 (1995).

8）滋賀の食事文化研究会：湖魚と近江のくらし. サンライ ズ出版, 滋賀 (2003).

9) Fujii, T., Watanabe, S., Horikoshi, M. and Bon Kimura, T.: PCR-DGGE, analysis of bacterial communities in funazushi, fermented crucian carp with rice, during fermentation. Fish Sci., 77: 151-157 (2011). 